\title{
Naprzemienne zatłaczanie wody i gazu (WAG) wspomagane pianą (FAWAG) jako efektywna metoda EOR w złożach szczelinowatych $i$ heterogenicznych
}

\author{
Foam Assisted Water Alternating Gas Injection as an effective EOR method in \\ heterogenous and fractured reservoirs
}

\author{
Mirosław Wojnicki \\ Instytut Nafty i Gazu - Państwowy Instytut Badawczy
}

\begin{abstract}
STRESZCZENIE: Zatłaczanie gazu w procesach wspomagania wydobycia ropy ( $\mathrm{z}$ ang. enhanced oil recovery - EOR) wiąże się z wystąpieniem niekorzystnego współczynnika mobilności, co często prowadzi do destabilizacji frontu wypierania, tworzenia się języków gazowych i przedwczesnego przebicia zatłaczanego płynu do odwiertów wydobywczych. Jedną z ciekawszych metod, która pozwala na skuteczną kontrolę mobilności gazu, jest naprzemienne zatłaczanie wody i gazu (z ang. water alternating gas - WAG). Łączy ona zalety większej skuteczności wolumetrycznego wypierania ropy (w skali makro) przy zatłaczaniu wody oraz lepszej efektywności wypierania ropy gazem w skali porowej. Największe krajowe nagromadzenia ropy naftowej zlokalizowane są w formacjach węglanowych, które posiadają cechy problematyczne dla procesów EOR, tj. silną heterogeniczność oraz szczelinowatość. Doświadczenia złożowe wskazują, że w takich przypadkach konwencjonalny proces WAG może nie być wystarczający, aby przeciwdziałać niekorzystnym, z punktu widzenia efektywności wypierania ropy, zjawiskom zachodzącym podczas przepływu zatłaczanych płynów. W celu wzmocnienia efektywności procesu WAG stosowane są odpowiednie środki chemiczne, pozwalające na wytworzenie piany, która znacząco ogranicza mobilność gazu i wyrównuje prędkość przepływu między matrycą skalną i systemem szczelin. System pianowy pozwala skierować przepływ zatłaczanych płynów poza strefy o zwiększonej przepuszczalności, zwiększając tym samym skuteczność wypierania ropy w matrycy skalnej. W artykule, który ma charakter przeglądowy, wyczerpująco przedstawiono założenia teoretyczne procesu naprzemiennego zatłaczania wody i gazu wspomaganego pianą ( $\mathrm{z}$ ang. foam-assisted WAG - FAWAG) oraz jego pozycję na tle pozostałych wariantów metody WAG. Omówiono zastosowanie piany w EOR, scharakteryzowano szczegółowo właściwości piany oraz przedstawiono zagadnienia jej stabilności w ośrodku porowatym. Przybliżono również kwestie mechanizmów odpowiedzialnych za generację piany w ośrodku porowatym. Na koniec krótko scharakteryzowano środki chemiczne stosowane w procesach EOR oraz podano przykłady zastosowań metody FAWAG w skali złożowej.
\end{abstract}

Słowa kluczowe: FAWAG, WAG, wspomaganie wydobycia ropy naftowej, EOR, piana, przepływ w ośrodku porowatym.

ABSTRACT: Gas injection in enhanced oil recovery (EOR) processes is associated with the occurrence of an unfavourable mobility factor. It often leads to the destabilisation of displacement front, viscous fingering and the early breakthrough of the injected fluids into extraction wells. One of the most interesting methods for effective controlling of gas mobility is water alternating gas injection (WAG). It combines the advantages of increased volumetric sweep efficiency (macro-scale) by water injection and improved efficiency of porescale oil displacement by gas injection. The largest domestic crude oil accumulations are located in carbonate formations which represent problematic features for EOR processes such as strong heterogeneity and fracturing. Field experience shows that in such cases a conventional WAG process may not be capable to counteract unfavourable (for displacement efficiency) phenomena occurring during the flow of injected fluids. Therefore, suitable chemicals are used to produce foam to enhance the WAG process efficiency. It significantly reduces the mobility of gas and equalises the flow velocity between the rock matrix and fractures. The foam system allows the flow of injected fluids to be directed out of the permeable zones, thus increasing the effectiveness of oil displacement in the rock matrix. In this review paper, detailed principles of the Foam Assisted WAG (FAWAG) process as well as its position among other WAG variants are presented. The application of foam is discussed. The properties of the foam are characterised in detail, and the issues of its stability in the porous medium are presented. The mechanisms responsible for the foam formation in a porous medium are also discussed. Finally, the chemical agents used in EOR processes are briefly characterised, and the examples of FAWAG reservoir scale implementation are presented.

Key words: FAWAG, WAG, Enhanced Oil Recovery, EOR, foam, flow in porous media.

Autor do korespondencji: M. Wojnicki, e-mail: miroslaw.wojnicki@inig.pl

Artykuł nadesłano do Redakcji: 06.12.2019 r. Zatwierdzono do druku: 25.04.2020 r. 


\section{Wprowadzenie}

Ponad 60\% światowych zasobów ropy naftowej znajduje się w węglanowych skałach zbiornikowych, które w większości przypadków charakteryzują się wysokim stopniem heterogeniczności i skomplikowanym systemem sieci porowej (Masalmeh et al., 2014). Przeważająca część kolektorów węglanowych posiada podwójny (matrycowo-szczelinowy) system porowatości, który znacząco wpływa na charakter przepływu płynów w ośrodku porowatym (Lubaś, 2006). Jest to spowodowane istotnym kontrastem między układem porowatości szczelinowej (z ang. fracture porosity), o wysokiej przepuszczalności, oraz układem porowatości matrycy skalnej (z ang. matrix porosity), o niskiej przepuszczalności. Rozbieżność $\mathrm{w}$ wartościach przepuszczalności między tymi dwoma współwystępującymi układami porowatości jest wysoka i może wynosić do kilku rzędów wielkości. Stanowi to dodatkowy problem, obok wysokiej mobilności zatłaczanego gazu względem pozostającej w złożu ropy, związany z wykorzystaniem gazu w procesach wspomagania wydobycia ropy. Skuteczną metodą ograniczania mobilności gazu jest naprzemienne zatłaczanie wody i gazu (WAG), łączące zalety dwóch szeroko stosowanych procesów, tj. zatłaczania wody (nawadniania) i zatłaczania gazu. WAG pozwala wykorzystać większą efektywność wypierania gazem w skali porowej (mikro) wraz z lepszą zdolnością wody do wolumetrycznego wypierania ropy w skali złożowej (makro) (Kulkarni i Rao, 2005). Metoda WAG jest opłacalna w perspektywie ograniczania ilości gazu wymaganego do zatłoczenia (Pariani et al., 1992) oraz korzystna z punktu widzenia środowiskowego - w przypadku wykorzystania ditlenku węgla, gazów kwaśnych i innych szkodliwych dla atmosfery gazów. Szacuje się, że ponad $80 \%$ złożowych implementacji metody WAG w USA przyniosło pożądane efekty (Sanchez, 1999). Proces WAG z sukcesem wdrożono również na polach naftowych Morza Północnego, m.in. Gullfaks, Stafjord, South Brae, Snorre i Oseberg Ost (Christensen et al., 2001). Największe polskie złoża ropy naftowej znajdują się w formacjach węglanowych i bezsprzecznie wymagają podjęcia działań na rzecz wdrożenia EOR (Lubaś, 2013). Prowadzone w INiG - PIB badania symulacyjne (Such i Szott, 1997) i wstępne badania laboratoryjne (Wojnicki, 2017a; Wojnicki et al., 2017) wykazały duży potencjał w zastosowaniu metody WAG na krajowych złożach ropy naftowej, co skłania do kontynuowania, a nawet zintensyfikowania prac w tym obszarze. Jednakże niektóre doświadczenia złożowe wskazują, że w silnie heterogenicznych i szczelinowatych formacjach węglanowych wykorzystanie procesu WAG może okazać się niewystarczające do kontroli mobilności zatłaczanego gazu. Aby temu zaradzić, stosowane są środki chemiczne wspierające proces WAG poprzez wytworzenie piany, co nazywane jest procesem WAG wspomaganym pianą (z ang. foam-assisted WAG - FAWAG).

\section{FAWAG na tle innych wariantów metody WAG}

Dla zwiększenia efektywności sczerpania, lepszego dostosowania do konkretnych warunków złożowych i usprawnienia pewnych niedociągnięć konwencjonalnego procesu WAG rozwijanych jest kilka jego wariantów (rys. 1). Biorąc pod uwagę schemat prowadzenia procesu, można wyróżnić „konwencjonalne" naprzemienne zatłaczanie wody i gazu (z ang. water alternating gas - WAG), równoczesne zatłaczanie wody i gazu ( $\mathrm{z}$ ang. simultaneous WAG - SWAG) oraz hybrydowe zatłaczanie wody i gazu (z ang. hybrid WAG - HWAG). W metodzie HWAG, nazywanej również Denver Unit WAG (DUWAG), konwencjonalny proces WAG jest poprzedzony zatłoczeniem jednej dużej porcji gazu. Nie do końca racjonalne jest włączanie SWAG do metod naprzemiennego zatłaczania (gaz i woda są mieszane na powierzchni i razem zatłaczane do złoża), jednak w takiej właśnie formie jest ona najczęściej klasyfikowana. Wariant SWAG wymaga mieszania się gazu z wodą przy ciśnieniu odpowiednim do zachowania przepływu pęcherzykowo-dyspersyjnego. Utrzymanie takiego przepływu jest dużym wyzwaniem ze względu na tendencję do separowania się wody i gazu. W przypadku SWAG występuje również problem związany z obniżeniem wydajności zatłaczania na skutek redukcji przepuszczalności, powodowany jednoczesną obecnością fazy gazowej i ciekłej (przepływ dwufazowy w strefie przyodwiertowej) (Anwar et al., 2006). Bardzo częstą praktyką jest stopniowe zmniejszanie ilości gazu w stosunku do ilości wody ( $\mathrm{z}$ ang. tapering), co czasem uznaje się za osobny wariant metody - TWAG ( $\mathrm{z}$ ang. tapered WAG) (Christensen et al., 1998; Verma, 2015; Wojnicki, 2017b).

Najistotniejsza klasyfikacja metody WAG jest oparta na warunkach mieszalności zatłaczanego gazu. Gaz może być zatłaczany $\mathrm{w}$ warunkach mieszania się $\mathrm{z}$ ropą - proces mieszający ( $\mathrm{z}$ ang. miscible WAG - MWAG) lub w reżimie niemieszającym (z ang. immiscible WAG - IWAG) (Sheng, 2013a). Proces mieszający jest szczególnie korzystny, gdyż w wyniku zmieszania się ropy z gazem zwiększa się jej objętość (pęcznienie), a zmniejsza lepkość oraz napięcie powierzchniowe. Wszystkie te czynniki pozytywnie wpływają na wzrost sczerpania ropy ze złoża. Mieszalność silnie zależy od warunków złożowych (temperatury, ciśnienia) oraz własności fazy wypieranej (ropy) i zatłaczanych płynów (wody i gazu). Dla osiągnięcia stanu zmieszania konieczne jest jednak zatłaczanie gazu w warunkach minimalnego ciśnienia zmieszania - MMP ( $\mathrm{z}$ ang. minimum miscibility pressure), które wyznacza się każdorazowo dla konkretnej pary płynów (ropy złożowej i zatłaczanego gazu). Często w przypadku złóż pracujących poniżej MMP, z powodów ekonomicznych lub technicznych, niestosowne lub niemożliwe jest podniesienie ciśnienia do osiągnięcia MMP (Christensen et al., 2001; Sheng, 2013a; Lake et al., 2014). 
Modyfikacje zatłaczania fazy gazowej w procesie WAG polegają na wykorzystaniu piany ( $\mathrm{z}$ ang. foam-assisted WAG - FWAG/FAWAG) oraz pary ( $\mathrm{z}$ ang. water alternating steam process - WASP). Wśród modyfikacji fazy ciekłej w procesie WAG można wyróżnić wykorzystanie wody o obniżonym zasoleniu (z ang. low-salinity water - LSW), wody modyfikowanej polimerami (z ang. polymer WAG - PAG lub PWAG), wody modyfikowanej środkami powierzchniowo czynnymi (z ang. surfactant alternating gas - SAG) lub emulsji typu olej w wodzie ( $\mathrm{z}$ ang. emulsions WAG - EWAG).

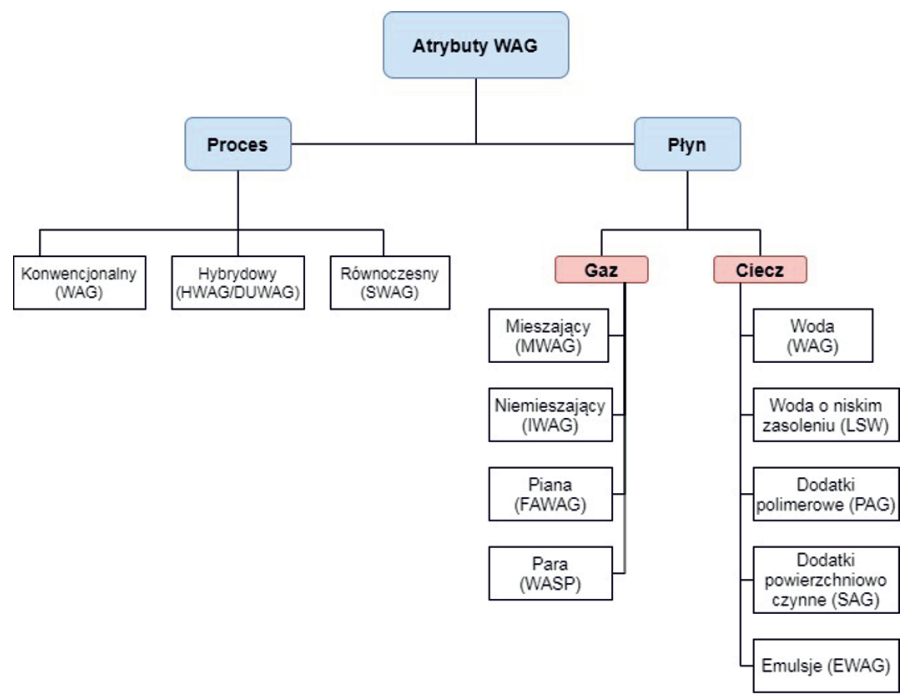

Rys. 1. Podział wariantów metody WAG (Afzali et al., 2018)

Fig. 1. Variations of the WAG method (Afzali et al., 2018)

\section{Zastosowanie piany w EOR}

Silna heterogeniczność i szczelinowatość formacji zbiornikowych może sprawiać, że nawet cykliczne zatłaczanie wody i gazu nie ograniczy wystarczająco mobilności zatłaczanego do złoża gazu. By lepiej przeciwdziałać powstawaniu języków gazowych i przedwczesnemu przebijaniu się zatłaczanego gazu do odwiertów wydobywczych, już w latach 60. ubiegłego stulecia zaproponowano dodatkowe ograniczenie mobilności zatłaczanego gazu przy użyciu piany. Piana znacząco obniża mobilność gazu poprzez przerwanie ciągłości fazy gazowej (Li et al., 2010). Piana może być generowana in situ w złożu, głównie w strefach wysokich przepuszczalności, w celu skierowania przepływu zatłaczanych płynów poza sieć szczelinową i strefy o zwiększonej przepuszczalności. Front piany porusza się z równą prędkością w strefach o różnych przepuszczalnościach, co znacząco stabilizuje przepływ i zwiększa objęcie złoża zasięgiem wypierania (Bertin et al., 1999) (rys. 2). Piana znacznie zwiększa efektywność wypierania w systemie szczelin oraz istotnie zmniejsza negatywny wpływ szczelin podłużnych na sczerpanie ropy (Yan et al., 2006).Wspomaganie wydobycia z zastosowaniem piany może być realizowane poprzez zatłaczanie piany przygotowanej na powierzchni, jednoczesne zatłaczanie roztworu środka pianotwórczego i gazu oraz naprzemienne zatłaczanie roztworu środka pianotwórczego i gazu. Sposób zatłaczania ma znaczny wpływ na właściwości piany (Turta i Singhal, 2002).

Piany przygotowane na powierzchni charakteryzują się bardzo wysoką lepkością pozorną i silnie ograniczają mobilność gazu. Są one w stanie całkowicie zablokować ośrodek porowaty, dlatego ten sposób zatłaczania znajduje zastosowanie w regulowaniu/blokowaniu przepływu w strefach o ekstremalnie wysokich przepuszczalnościach. Ich użycie wiąże się z wysokimi stratami chłonności, a co za tym idzie - z większymi wydatkami energetycznymi na tłoczenie.

Piany tworzone wskutek jednoczesnego zatłaczania roztworu pianotwórczego i gazu mają zwykle mniejszą zdolność redukowania mobilności gazu niż piany przygotowane na powierzchni. Ten sposób zatłaczania sprawdza się w strefach o wysokiej przepuszczalności, a nie jest polecany w przypadku złóż o średnich i niskich przepuszczalnościach ze względu na znaczące straty chłonności.

Najczęściej stosowanym sposobem implementacji piany dla celów EOR jest generacja jej in situ w złożu poprzez naprzemienne zatłaczanie wody z dodatkiem rozpuszczonych środków pianotwórczych (powierzchniowo czynnych) i gazu (Farajzadeh et al., 2009). Taka forma implementacji jest najkorzystniejsza w przypadku złóż charakteryzujących się średnią i niską przepuszczalnością, gdyż ma znikomy wpływ na chłonność odwiertu.

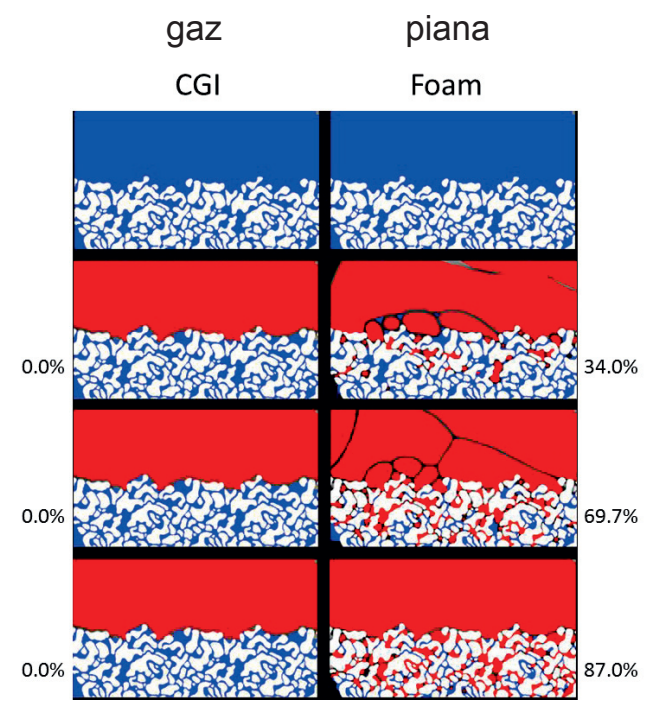

Rys. 2. Porównanie efektywności wypierania płynu z matrycy skalnej w obecności systemu szczelinowego podczas zatłaczania gazu (lewa kolumna) i piany (prawa kolumna) w czterech krokach czasowych. Kolor czerwony to gaz, biały - ziarna matrycy, a niebieski to roztwór wodny. Wartość procentowa oznacza efektywność wypierania z przestrzeni porowej matrycy (Gauteplass et al., 2015)

Fig. 2. Comparison of fluid displacement efficiency in fractured rock matrix system during continuous gas injection (left column) and foam injection (right column). Rock matrix is white, aqueous solution is blue and gas is marked in red (Gauteplass et al., 2015) 
Zatłaczanie gazu
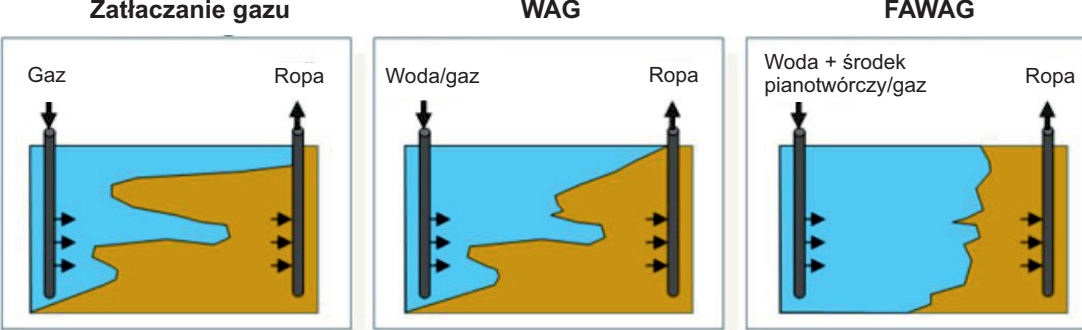

Rys. 3. Porównanie stabilności frontu wypierania w zatłaczaniu gazu i metodach WAG oraz FAWAG (Afzali et al., 2018)

Fig. 3. Comparison of displacement front stability between continuous gas injection, WAG and FAWAG (Afzali et al., 2018)

Różnorodność nazw, pod jakimi w literaturze opisywany jest proces wspomagania wydobycia ropy z użyciem piany, może być myląca. Stosowanie różnych nazw w stosunku do bardzo podobnych (a nawet identycznych) procesów, tak jak w przypadku FAWAG i SAG (z ang. surfactant alternating gas) powoduje jedynie zamieszanie i należy tego unikać. Określenia odnoszące się do wspomagania wydobycia ropy naprzemiennym zatłaczaniem wody i piany, oprócz wcześniej wymienionych FAWAG i SAG (używanych zamiennie), to np. ASG (z ang. alkali-surfactant-gas), ASF (z ang. alkali-surfactant foam), PEF ( $\mathrm{z}$ ang. polymer-enhanced foam), ASPF (z ang. alkali-surfactant-polymer foam). Pomimo wielu odmian i ponad 60 lat intensywnych badań wspomaganie wydobycia $\mathrm{z}$ wykorzystaniem piany jest $\mathrm{w}$ dalszym ciągu niedojrzałą technologią, która budzi w ostatnich latach duże zainteresowanie, co związane jest z intensyfikacją stosowania $\mathrm{CO}_{2} \mathrm{w}$ procesach EOR.

W porównaniu do tradycyjnego procesu WAG wykorzystanie piany w procesie FAWAG może wpływać na zwiększenie sczerpania ropy ze względu na:

- dodatkową stabilizację frontu wypie-

Tabela 1. Zakres stosowalności piany w EOR dla parametrów złożowych i procesowych Table 1. The range of reservoir and process parameters for the foam EOR application

\begin{tabular}{|l|c|c|}
\hline \multicolumn{1}{|c|}{ Parametr } & Zakres & Komentarz \\
\hline \hline Miąższość formacji zbiornikowej $[\mathrm{m}]$ & $3-350$ & \\
\hline Przepuszczalność $[\mathrm{mD}]$ & $1-5000$ & \\
\hline Temperatura złożowa $\left[{ }^{\circ} \mathrm{C}\right]$ & $<101$ & $\begin{array}{c}\text { kilka projektów powyżej } 101^{\circ} \mathrm{C}, \\
\text { najwyższa raportowana: } 232^{\circ} \mathrm{C}\end{array}$ \\
\hline Ciśnienie złożowe $[\mathrm{bar}]$ & $<500$ & \\
\hline Lepkość ropy [cP] & $<10000$ & \\
\hline Gęstość siatki odwiertów [m] & $30-1500$ & \\
\hline $\begin{array}{l}\text { Całkowita zawartość rozpuszczonych } \\
\text { substancji stałych }\end{array}$ & $<180000$ & w zależności od użytego środka \\
\hline Stężenie środka pianotwórczego [\%] & $<1$ & \\
\hline
\end{tabular}
rania poprzez zwiększenie lepkości płynu wypierającego;

- blokowanie stref o wysokiej przepuszczalności i skierowanie zatłaczanych płynów do stref nieobjętych wypieraniem;

- obniżanie sił kapilarnych poprzez obniżenie napięcia powierzchniowego (dzięki obecności środków powierzchniowo czynnych).

\section{Kryteria stosowalności}

Ze względu na to, że w metodzie FAWAG wykorzystywane są środki chemiczne pozwalające na wytworzenie piany, kryteria stosowalności są bardzo podobne do pozostałych na temperatury $>150^{\circ} \mathrm{C}$;

- stosunkowo gęsta siatka odwiertów wydobywczych;

- stosunkowo niskie nasycenie ropą, pozwalające na tworzenie stabilnej piany.

Sheng w swojej pracy (Sheng, 2013b) przeanalizował ponad 60 projektów zatłaczania piany w skali złoża, co pozwoliło na podsumowanie zakresu stosowalności dla parametrów złożowych i procesowych na podstawie doświadczeń złożowych (tabela 1). metod EOR wspieranych chemicznie, takich wierzchniowo czynnych. Jedne z najważniejszych kryteriów to:

złoża heterogeniczne ze strefami o wysokich przepuszczalnościach; gólnie z niską zawartością jonów dwuwar-

- temperatura złożowa $<100^{\circ} \mathrm{C}$ - to założenie jest już w dużej mierze nieaktualne, gdyż niektóre nowe środki chemiczne są odporne 
tworzy się pryzmatyczna strefa wypełniona cieczą, nazywana granicą Plateau (obszar styku trzech lameli oznaczony kółkiem na rys. 4). Szerokość tego regionu jest zależna od ciśnienia kapilarnego. Wraz ze wzrostem ciśnienia grubość lameli zmniejsza się do momentu osiągnięcia minimalnej grubości (krytycznej), przy której lamela się rozpada. Ciśnienie rozklinowujące (z ang. disjoining pressure) jest różnicą między ciśnieniem w obszarze fazy przyległym do ograniczającej go powierzchni i ciśnieniem w całkowitej objętości tej fazy (Prud'homme i Khan, 1996).

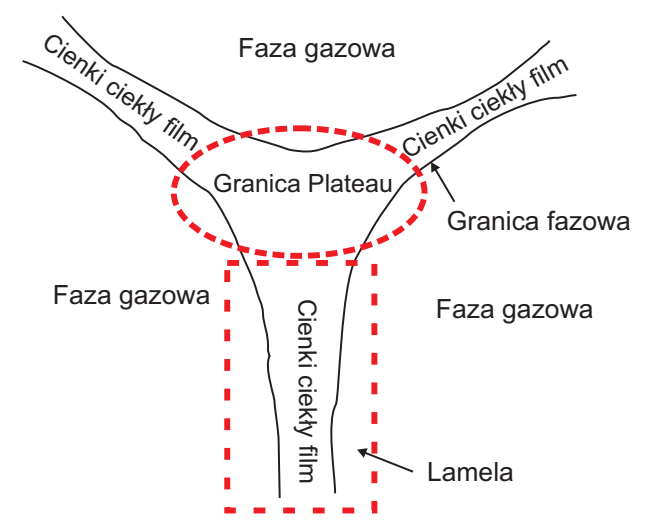

Rys. 4. Schemat systemu pianowego (Sheng, 2013a)

Fig. 4. Foam system pattern (Sheng, 2013a)

Piana składająca się ze sferycznych pęcherzyków gazu rozdzielonych stosunkowo grubymi warstwami cieczy nazywana jest mokrą pianą, podczas gdy piana zbudowana $\mathrm{z}$ wielościennych pęcherzyków gazu określana jest jako sucha piana. Piana może być również klasyfikowana jako piana z ciągłą fazą gazową, w której występuje co najmniej jedna ścieżka przepływu gazu w sieci porowej nieblokowana przez lamele (rys. 5). Piana z nieciągłą fazą gazową to taka, w której wszystkie ścieżki przepływu gazu blokowane są przez lamele (rys. 5).

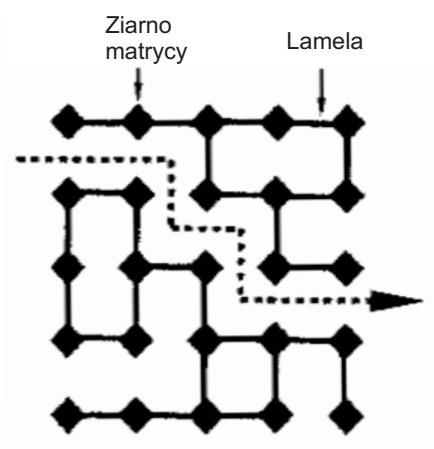

Piana z ciągłą fazą gazową

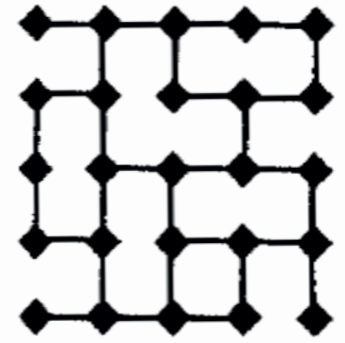

Piana z nieciągłą fazą gazową
Rys. 5. Schematyczny obraz ciągłości fazy gazowej w pianie (Prud'homme i Khan, 1996)

Fig. 5. Schematic diagram of the continuity of the gas phase in foam (Prud'homme i Khan, 1996)
W praktyce niemożliwe jest rozróżnienie ciągłości fazy gazowej w pianie obecnej w ośrodku porowatym, gdyż nie można zweryfikować pozycji, przemieszczania się lub nawet określić obecności lameli w skale. Dlatego z praktycznego punktu widzenia piana w ośrodku porowatym definiowana jest jako redukcja mobilności gazu w obecności wodnego roztworu środka pianotwórczego poniżej wartości obserwowanej przy tym samym nasyceniu wodą (Prud'homme i Khan, 1996).

Zwykle cieczą w pianie jest woda. W niektórych przypadkach cieczą mogą być płyny węglowodorowe lub kwasy. Pianę można utworzyć przez wzburzenie cieczy zawierającej niewielką ilość środka pianotwórczego (środka powierzchniowo czynnego) i połączenie jej z gazem. Piany bez środka pianotwórczego są niestabilne i szybko się rozbijają. Dlatego też w większości przypadków piana jest mieszaniną gazu, wody i środka pianotwórczego (środka powierzchniowo czynnego).

Stosunek cieczy i gazu oraz tekstura piany są głównymi parametrami charakteryzującymi reologię pian (Lee i Kam, 2013). Skuteczność spieniania danego roztworu jest określana poprzez stabilność piany i spienialność. Najważniejsze właściwości piany to:

- jakość piany - jest wyrażona w postaci ułamka lub procentu objętości gazu w pianie. Jakość piany zawiera się zazwyczaj w przedziale od $75 \%$ do $90 \%$;

- tekstura piany - odnosi się do liczby lameli na jednostkę objętości. Jest również wyrażana jako gęstość lameli lub gęstość pęcherzyków i odnosi się do wielkości pęcherzyków;

- stabilność piany - jest miarą tego, jak pożądane właściwości piany zmieniają się wraz z upływającym czasem po utworzeniu piany;

- spienialność - przedstawia, z jaką łatwością dany roztwór może wytworzyć pianę. Określa się ją podczas tworzenia piany.

Wielkość pęcherzyków jest rozpatrywana w kategoriach średniej średnicy i rozkładu wielkości pęcherzyków. Średnia wielkość pęcherzyków i rozkład ich wielkości mogą się znacznie różnić w zależności od piany, od wielkości koloidalnej $(0,01-0,1 \mu \mathrm{m})$ do dziesiątych części milimetra (Weaire, 2008). Jakość piany jest ściśle zależna od wielkości pęcherzyków. Wraz ze wzrostem wielkości pęcherzyków piany stają się mniej stabilne i ich jakość się zmniejsza. Do wytworzenia i stabilizacji piany wymagany jest odpowiednio dobrany środek pianotwórczy. W celu doboru takiego środka niezbędne jest przeprowadzenie odpowiednich testów, które określają zdolność do wytwarzania i stabilizacji piany oraz jej mobilność.

Ciekły film stabilizowany środkiem powierzchniowo czynnym (pianotwórczym), nazywany lamelą, może być traktowany jako powierzchnia matematyczna. Powierzchnia piany jest proporcjonalna do energii systemu, podczas gdy napięcie powierzchniowe jest stałą proporcjonalności. 


\section{Stabilność piany}

Piany nie są stabilne termodynamicznie i po pewnym czasie ulegają rozbiciu. Termin ,stabilność” oznacza względną stabilność w sensie kinetycznym. Stabilność piany jest determinowana szeregiem czynników dotyczących zarówno roztworu, jak i właściwości międzyfazowych. Metodą oceny stabilności piany jest pomiar jej czasu półtrwania lub średniej długości życia. Poniżej zaprezentowano ważniejsze zagadnienia związane ze stabilnością piany.

\section{- Wptyw ropy naftowej na stabilność piany}

Interakcje między ropą a pianą są szczególnie istotne ze względu na wykorzystanie piany do kontroli mobilności przy FAWAG. Gdy kropla ropy dostanie się na powierzchnię wodno-gazową, piana ulegnie zniszczeniu. Ropa niszczy film pianowy poprzez rozprzestrzenianie się po obydwu jego stronach, wypierając tym samym oryginalną ciecz filmu i pozostawiając film ropny, który jest niestabilny i łatwo ulega zniszczeniu. Stabilność pseudoemulsyjnego filmu jest czynnikiem kontrolującym stabilność trójfazowych pian w ośrodku porowatym (Manlowe i Radke, 1990). Destabilizacja piany w obecności fazy ropnej może zachodzić poprzez: rozkład środków powierzchniowo czynnych w fazie ropnej, rozprzestrzenianie się ropy na lamelach piany i wypieranie stabilizującej powierzchni międzyfazowej, samorzutną emulgację ropy i naruszenie przez jej krople stabilizującej granicy fazowej. Jeżeli piana zatłaczana jest do stref o niskim nasyceniu ropą, w celach kontroli mobilności, wystarczy, by posiadała średnią lub niską tolerancję na ropę. Natomiast jeśli piana zatłaczana jest jako płyn wypierający ropę naftową, to niezbędna jest wysoka stabilność w kierunku ropy (Farajzadeh et al., 2012; Lee i Kam, 2013). Na rysunku 6 przedstawiono wpływ ropy naftowej na stabilność frontu zatłaczanej piany. Widoczne na nim obrazy tomografii komputerowej prezentują rdzeń nasycony wodą (kolor czerwony) i ropą pozostałą po nawadnianiu (kolor pomarańczowy). Początkowo stabilny front piany (kolor niebieski), docierając do strefy nasyconej ropą, zostaje przerwany na skutek oddziaływania ropy naftowej na stabilność piany.

\section{- Wplyw ciśnienia i temperatury}

Wraz ze wzrostem ciśnienia pęcherzyki stają się mniejsze. Ciekły film zwiększa swoją powierzchnię i staje się cieńszy, co prowadzi do wolniejszego odpływu cieczy. Wyższe ciśnienie pomaga stabilizować pęcherzyki, jednak za wysokie może prowadzić do ich rozbicia. Wraz ze wzrostem temperatury zwiększa się rozpuszczalność środków pianotwórczych w fazie ciekłej, co prowadzi do niższego stężenia środka na granicy faz gaz-ciecz. Wyższa temperatura powoduje również szybszy odpływ cieczy (Haugen et al., 2014).

- Odpływ cieczy spowodowany grawitacja

Grawitacja prowadzi do odpływu cieczy, przez co ciekły film staje się coraz cieńszy. Ostatecznie powoduje to łączenie się pęcherzyków i rozbicie piany. $Z$ tego punktu widzenia niskie nasycenie fazą ciekłą zmniejsza stabilność piany (Lee i Kam, 2013).

- Wptyw lepkości cieczy

Większa lepkość cieczy spowalnia odpływ cieczy powodowany grawitacją. Dane eksperymentalne wskazują również, że większa lepkość cieczy prowadzi do tworzenia bardziej stabilnych pian (Farajzadeh et al., 2012).

- Wplyw zwilżalności

Piany są mniej stabilne w obecności ropy naftowej i powierzchni ropozwilżalnych w porównaniu do tej samej ropy i powierzchni wodozwilżalnych (Farajzadeh et al., 2009).

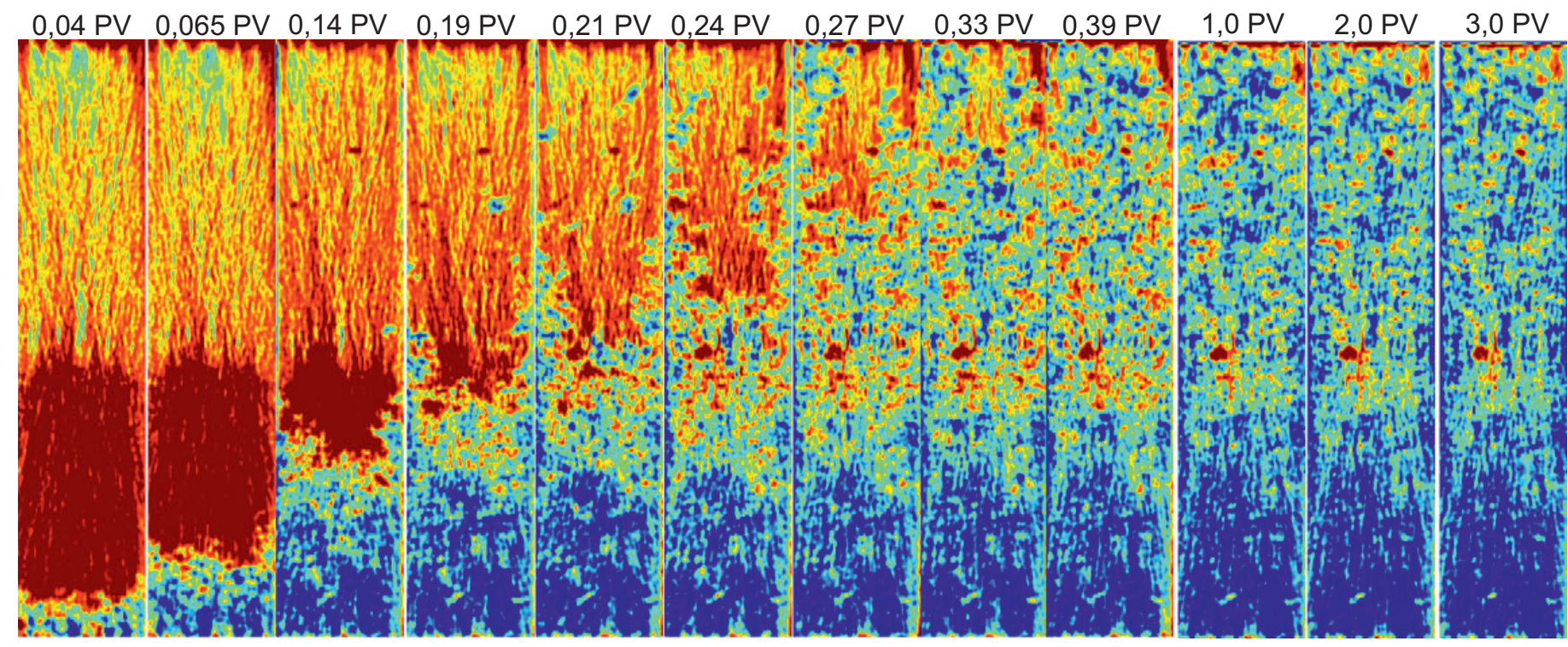

Rys. 6. Wpływ ropy naftowej na stabilność piany w ośrodku porowatym (Farajzadeh et al., 2012)

Fig. 6. Impact of crude oil on the foam stability in porous media (Farajzadeh et al., 2012) 


\section{- Wpływ wielkości pęcherzyków}

Pęcherzyki w pianie mają średnicę zwykle $>10 \mu \mathrm{m}$ i mogą być większe niż $1000 \mu \mathrm{m}$. Stabilność piany nie jest jedynie funkcją wielkości pęcherzyka, jednak może istnieć jej optymalna wielkość dla określonego typu piany. Niektóre piany posiadające rozkład wielkości pęcherzyków silnie nacechowany w kierunku mniejszych średnic reprezentują najbardziej stabilne piany. Wpływ wielkości pęcherzyków można bardziej ogólnie określić jako wpływ tekstury piany, do której zalicza się wielkość i kształt pęcherzyków oraz ich rozkład w matrycy piany. Piany mają większą stabilność, jeżeli rozkład wielkości pęcherzyków jest jednolity (Lee i Kam, 2013).

\section{- Wplyw obecności dodatkowych faz}

Na stabilność piany może wpływać obecność innych rozpuszczonych substancji, dodatkowej fazy ciekłej, takiej jak olej w pianie wodnej, lub drobnoziarnista faza stała. To, czy będą one miały pozytywny, czy negatywny wpływ na stabilność piany, zależy od kilku czynników. Dodanie do systemu pianowego jakiejkolwiek rozpuszczalnej substancji, która znajdzie się na granicy faz może obniżyć dynamiczną stabilność piany, jeśli substancja ta wpływa na zwiększenie napięcia powierzchniowego, obniżenie elastyczności powierzchni międzyfazowej, obniżenie lepkości powierzchni fazowej lub obniżenie potencjału powierzchniowego (Schramm, 1994). Obecność cząsteczek rozproszonych może zwiększać lub zmniejszać stabilność piany. Jednym z mechanizmów odpowiedzialnych za polepszenie stabilności jest zwiększenie lepkości na skutek stabilnej dyspersji cząstek obecnych w roztworze. Drugi mechanizm stabilizujący jest obecny, jeśli cząstki nie są całkowicie zwilżone wodą. W takim przypadku cząstki mają tendencję do gromadzenia się na granicy fazowej piany, gdzie mogą przyczyniać się do mechanicznej stabilizacji lameli (Schramm, 1994; Prud'homme i Khan, 1996).

\section{Środki spieniające w EOR}

Na stabilność piany wpływa wiele czynników, co szczegółowo opisano powyżej, dlatego bardzo istotny jest staranny dobór środków powierzchniowo czynnych do danych warunków złożowych. Są one niezbędne do wytworzenia systemu pianowego i utrzymania jego stabilności. Niektóre środki powierzchniowo czynne posiadające dobre właściwości pieniące nie są skuteczne w obniżaniu napięcia powierzchniowego. W większości projektów EOR stężenie spieniających środków powierzchniowo czynnych było mniejsze niż 1\%, średnio jest to $0,5 \%$. W niektórych przypadkach wartości mniejsze od $0,1 \%$ okazywały się wystarczające (Lee i Kam, 2013). Podczas oceny i doboru środków powierzchniowo czynnych należy wziąć pod uwagę następujące aspekty:
- zdolność do tworzenia piany;

- stabilność;

- odporność termiczną;

- odporność na zasolenie i jony multiwalencyjne;

- kompatybilność z płynami złożowymi;

- zdolność obniżania napięcia powierzchniowego;

- adsorpcję na powierzchni skały.

Do środków powierzchniowo czynnych, które z powodzeniem wykorzystano w warunkach złożowych, należą (Zhang et al., 2005):

- ORS-41 (alkilobenzenosulfonian) i AOS (sulfonian alfaolefin) - przy niskich temperaturach $\left(\sim 45^{\circ} \mathrm{C}\right)$ i niskim zasoleniu $(<10000 \mathrm{ppm})$;

- DP-4 (produkcja chińska) - stabilność temperaturowa do $60^{\circ} \mathrm{C}$, zasolenie do $17000 \mathrm{ppm}, 1000 \mathrm{ppm} \mathrm{Ca}^{2+} \mathrm{i} \mathrm{Mg}^{2+}$;

- AGES (produkcja chińska) - stabilność temperaturowa do $250^{\circ} \mathrm{C}$, zasolenie do $50000 \mathrm{ppm}, 1000 \mathrm{ppm} \mathrm{Ca}^{2+} \mathrm{i} \mathrm{Mg}^{2+}$.

$\mathrm{W}$ badaniach laboratoryjnych i testach złożowych raportowano również wykorzystanie środków takich jak: SuntechIV (Sun), DowFax 2A (Dow), Neoden 14-16 i Neoden 16-18 (Shell), Stepanflo 30 (Stepan), Chaser CD 1040-1050 (Chevron), Enordet (Shell), Witcolate i Witconate AOS (Nouryon), Alipal CD-128, Avanel S-30 (Xue et al., 2015; Ahmed et al., 2017; Liu et al., 2020).

Czasami tradycyjnie używane komercyjne niejonowe lub anionowe środki powierzchniowo czynne są nieodpowiednie do zastosowań w wysokotemperaturowych i wysokociśnieniowych formacjach węglanowych. Punkt zmętnienia oksyetylenowanych niejonowych środków powierzchniowo czynnych przekracza $100^{\circ} \mathrm{C}$, a rozpuszczalność większości niejonowych środków powierzchniowo czynnych zmniejsza się wraz ze wzrostem zasolenia solanki. Dodatkowo są one silnie adsorbowane w obecności rozpuszczonego $\mathrm{CO}_{2}$ na dodatnio naładowanej powierzchni skał węglanowych (Wang et al., 2015). Kationowe środki powierzchniowo czynne wykazują niską adsorpcję na powierzchniach skał węglanowych, jednak z drugiej strony są słabo rozpuszczalne w obecności $\mathrm{CO}_{2}$. Aby pokonać te ograniczenia, zaprojektowano oksyetylenowane aminowe środki powierzchniowo czynne o zmiennym charakterze - od niejonowego do kationowego. Oksyetylenowane aminy zmieniają się z niejonowych do kationowych w obecności kwaśnej fazy wodnej (np. z rozpuszczonym $\mathrm{CO}_{2}$ ). Sa one dobrze rozpuszczalne w obecności $\mathrm{CO}_{2}$, a jednocześnie poprzez dodatni ładunek aminy są bardziej hydrofilne, a ich punkt zmętnienia wzrósł do $120^{\circ} \mathrm{C}$. Co najważniejsze, adsorpcja na powierzchniach węglanowych została znacznie zredukowana ze względu na obecność grupy kationowej. Dlatego oksyetylenowane aminy o zmiennym charakterze są rozpatrywane jako środki powierzchniowo czynne nowej generacji, które doskonale łączą najlepsze cechy środków jonowych (wysoki punkt zmętnienia) 
i niejonowych (rozpuszczalność w wodzie z obecnością $\mathrm{CO}_{2}$ ), stabilizując pianę $\mathrm{w}$ temperaturach $\sim 120^{\circ} \mathrm{C} \mathrm{z}$ minimalną adsorpcją na powierzchniach węglanowych.

\section{Powstawanie piany w ośrodku porowatym}

Formowanie piany w ośrodku porowatym może zachodzić w wyniku jednego z trzech przedstawionych poniżej mechanizmów.

\section{- Proces odłączenia (snap-off)}

Zachodzi, gdy gaz wpływa do porów wypełnionych roztworem pianotwórczym (rys. 7). Ekspansja gazu tworzy gradient ciśnienia kapilarnego pomiędzy przestrzenią poru a jego gardzielą (strefą niższego ciśnienia), powodując cofnięcie się cieczy i gromadzenie się jej w gardzieli poru. Jeżeli zgromadzi się tam wystarczająca ilość cieczy, to powstaje nowa lamela. Ten mechanizm generuje stabilne i tzw. silne piany, w których wielkość pęcherzyka jest rzędu wielkości przestrzeni porów. Uważa się, że jest to dominujący mechanizm tworzenia się piany. Powstałe pęcherzyki mogą gromadzić się w pewnej lokalizacji ośrodka porowatego, blokując przepływ gazu i obniżając jego przepuszczalność (Manlowe i Radke, 1990; Lee i Kam, 2013).

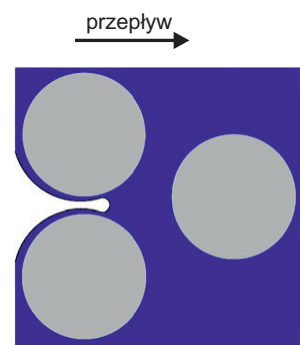

a)

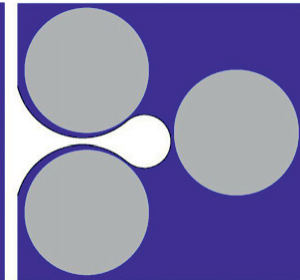

b)

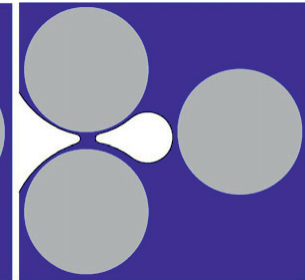

c)
Rys. 7. Powstawanie piany w procesie odłączenia (snap-off) (Almajid i Kovscek, 2016)

Fig. 7. Foam generation by the snap-off process (Almajid i Kovscek, 2016)

\section{- Proces podziału lameli (z ang. lamella division)}

Jest to proces, który występuje jedynie wtedy, gdy lamele są już utworzone i mogą poruszać się w obrębie ośrodka porowatego. Kiedy przepływająca lamela dosięga punktu rozgałęzienia i dotyka ścianek na styku rozgałęzienia przepływu, może się podzielić na dwie lamele, które następnie podążają innymi ścieżkami (rys. 8). Mechanizm ten prowadzi do zwiększenia liczby lameli piany (oraz pęcherzyków) w ośrodku porowatym, a tym samym do zdrobnienia tekstury piany. Drobniejsza tekstura piany zwiększa opór hydrodynamiczny (Farajzadeh et al., 2012; Haugen et al., 2012) przez nagromadzenie lameli i ostatecznie zapobiega przepływowi piany do zajętych przestrzeni porowych. Na początku piana spontanicznie zajmuje strefy o mniejszym oporze (większej przepuszczalności), a dopiero później przemieszcza się do innych stref (o mniejszej przepuszczalności). Taki mechanizm czyni pianę dobrym medium rozdzielającym przepływ.

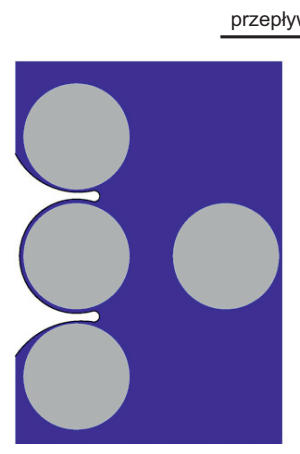

a)

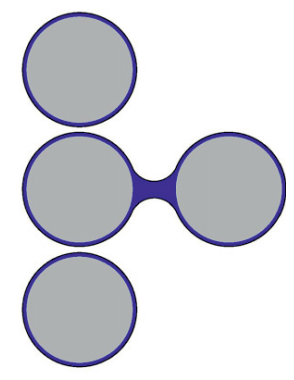

b)
Rys. 8. Powstawanie piany w procesie podziału lameli (lamella division) (Almajid i Kovscek, 2016)

Fig. 8. Foam generation by the lamella division process (Almajid i Kovscek, 2016)

\section{- Proces pozostawienia (z ang. leave-behind)}

Podobnie jak proces odłączenia zachodzi on, gdy gaz wkracza do porów wypełnionych roztworem pianotwórczym. Dwa gazowe fronty przepływają przez sąsiednie pory, pozostawiając soczewki cieczy w gardzieli porów, które łączą obydwie ścieżki przepływu (rys. 9). Podobnie dzieje się, gdy gaz płynący z dwóch różnych kierunków wpływa do tego samego poru, zatrzymując ciecz w gardzieli poru pomiędzy dwoma frontami, tworzac tym samym lamele. Proces pozostawiania jest związany z niestabilnymi pianami, gdyż pozwala jedynie na umiarkowane zwiększenie oporów dla przepływu gazu (Schramm, 1994).

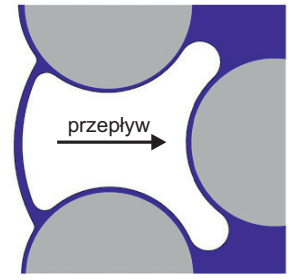

a)

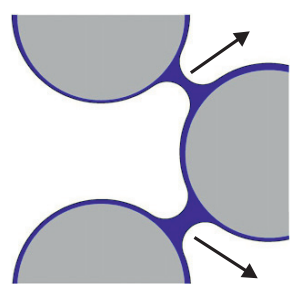

b)
Rys. 9. Powstawanie piany w procesie pozostawienia (leave-behind) (Almajid i Kovscek, 2016)

Fig. 9. Foam generation by the leave-behind process (Almajid \& Kovscek, 2016)

\section{Stany piany}

Piany w ośrodkach porowatych mogą występować w dwóch różnych stanach, charakteryzowanych przez teksturę piany lub gęstość występowania lameli (rys. 10). Piany niestabilne 
posiadają niewiele lameli (gruba tekstura) i nie są zbyt skuteczne w redukowaniu mobilności gazu. Piany stabilne mają wiele lameli (bardzo drobna tekstura), co prowadzi do skutecznego zwiększenia lepkości piany o kilka rzędów wielkości, tym samym wpływając na gwałtowny wzrost gradientu ciśnienia i obniżenie nasycenia wodą (Lee i Kam, 2013).

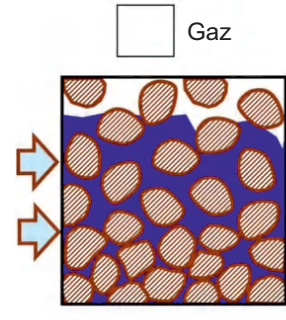

a) Gaz-ciecz (bez piany)

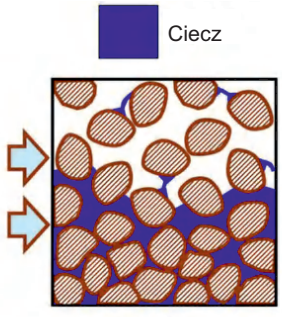

b) Słaba piana

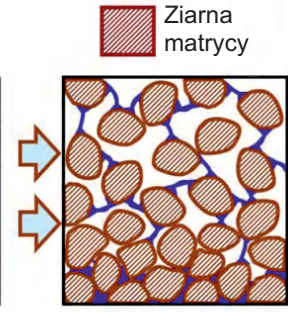

c) Silna piana
Rys. 10. Schematyczne rysunki przedstawiające różne rodzaje przepływu przez ośrodek porowaty: a) konwencjonalny przepływ dwufazowy gaz-ciecz, b) przepływ piany niestabilnej oraz c) przepływ piany stabilnej (Sheng, 2013a)

Fig. 10. Schemes presenting different types of flow in porous media: a) conventional two-phase gas-liquid flow, b) weak foam flow, and c) strong foam flow (Sheng, 2013a)

Reologiczne zachowanie przepływu piany wykazuje następujące cechy:

- na początku lepkość pozorna piany wzrasta wraz ze zwiększającą się prędkością do osiągnięcia wartości maksymalnej;

- następnie lepkość pozorna piany zmniejsza się wraz z dalszym zwiększaniem się prędkości powyżej wartości maksymalnej (zmniejszanie lepkości wraz ze wzrostem ścinania); - ostatecznie lepkość pozorna piany wykazuje histerezę, gdy wraz z obniżeniem prędkości lepkość spada poniżej wartości maksymalnej zaobserwowanej wcześniej.

Zmniejszanie lepkości wraz ze wzrostem ścinania jest korzystne dla zastosowań EOR, gdyż lepkość w strefie odwiertu zatłaczającego (gdzie generowana jest piana) jest mniejsza niż w dalszej części złoża. Takie zachowanie skutkuje mniejszymi stratami chłonności i lepszą efektywnością wypierania z dalszych części złoża.

\section{Zastosowania FAWAG/SAG w skali złożowej}

Wspomaganie wydobycia ropy naftowej z wykorzystaniem piany zaproponowano w 1958 roku, a pierwsze testy złożowe wykonano w 1964 r. na polu naftowym Siggins. Niemniej jednak stosowanie piany na szeroką skalę złożową nastąpiło dopiero w latach 80 . Pierwsze projekty z wykorzystaniem $\mathrm{CO}_{2}$ rozpoczęły się w 1984 r. i trwały do drugiej połowy lat 90. Jak do tej pory większość projektów FAWAG zrealizowano $\mathrm{w}$ formacjach piaskowcowych, a jedynie kilka raportowano ze złóż węglanowych (Sheng, 2013a). Poniżej przedstawiono dwa najistotniejsze przykłady wykorzystania piany w warunkach złożowych.

\section{- Snorre (Norwegia)}

Przykładem wykorzystania piany w największej jak dotąd skali jest projekt FAWAG zrealizowany na polu naftowym Snorre, zlokalizowanym w norweskim sektorze Morza Północnego. W ramach projektu zatłoczono ponad 2000 ton środka powierzchniowo czynnego (sulfonianu alfa-olefiny), na co złożyły się dwa testy zatłaczalności: jeden pełnoskalowy test przy zatłaczaniu naprzemiennym (FAWAG) i jeden pełnoskalowy test jednoczesnego zatłaczania (jednoczesne zatłaczanie wody ze środkiem pianotwórczym i gazu - piana tworzy się już w odwiercie). Eksploatację pola rozpoczęto w 1992 r., wykorzystując nawadnianie jako metodę wtórną wydobycia, a następnie dla ograniczenia mobilności gazu szybko rozpoczęto wdrażanie metody WAG (1995 r.). W 1997 r. rozpoczęto zatłaczanie FWAG, które realizowano do $2000 \mathrm{r}$. Zatłaczanie środków pianotwórczych prowadzono w dwóch cyklach. Pierwszy cyk1, przy stężeniu 0,49\% wag., trwał 10 dni z następującym zatłaczaniem gazu przez 100 dni. Drugi cykl, przy stężeniu $0,2 \%$ wag., realizowany był przez 20 dni. Projekt okazał się sukcesem - wygenerowana silna piana skutecznie ograniczyła mobilność zatłaczanego gazu. Wykładnik gazowy zmniejszył się z 400 (przed FAWAG) do 250 (po zastosowaniu FAWAG) pomimo wykorzystania większej ilości gazu w FAWAG. Przebicie gazu do odwiertów wydobywczych po zastosowaniu FAWAG następowało po $\sim 7$ miesiącach, podczas gdy wcześniej gaz przebijał się już po upływie jednego miesiąca. Jednocześnie odnotowano znaczący wzrost wydobycia ropy naftowej (rys. 11). Z punktu widzenia ekonomicznego był to niebywały sukces, gdyż wydatki na FAWAG (w części pola Western Fault Block) wyniosły $\sim 1 \mathrm{mln}$ USD, natomiast zyski ze sprzedaży dodatkowej ilości ropy naftowej 35-40 mln USD (przy cenach ropy z 2000 r.) (Blaker et al., 2002).

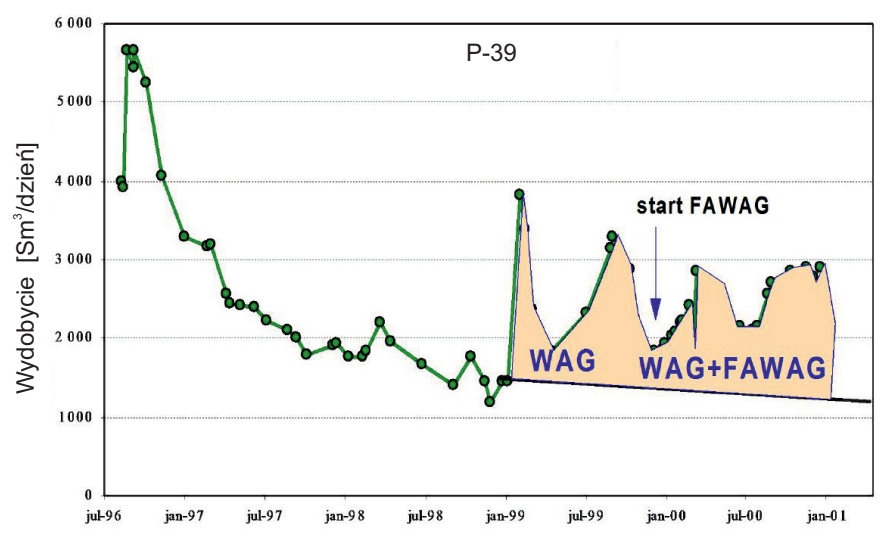

Rys. 11. Przebieg wydobycia na polu Snorre na przykładzie odwiertu P-39 (Blaker et al., 2002)

Fig. 11. Production from the Snorre oil field based on P-39 oil well (Blaker et al., 2002) 
- East Vacuum Grayburg/San Andres Unit - EVGSAU (Nowy Meksyk)

Przykład ten stanowi najlepiej udokumentowany pilotażowy projekt zatłaczania piany $\mathrm{CO}_{2}$. Pole naftowe zlokalizowane jest w heterogenicznych węglanowych skałach zbiornikowych basenu permskiego. Złoże początkowo pracowało przy zastosowaniu nawadniania, a następnie $\mathrm{z}$ wykorzystaniem procesu WAG. Szybki proces SAG został zaimplementowany w odpowiedzi na przedwczesne przebicie gazu do odwiertów wydobywczych, spowodowane występowaniem stref o zwiększonej przepuszczalności. Był to techniczny sukces, gdyż piana pozwoliła przekierować ponad $15 \%$ zatłaczanych płynów poza strefę chłonną na inne strefy złoża, co obniżyło wykładnik gazowy o połowę i pozwoliło podwoić wydobycie ropy (rys. 12). Z ekonomicznego punktu widzenia sukces był jednak pomniejszony ze względu na niskie ceny ropy w czasie realizacji pilotażowego zatłaczania. $\mathrm{Na}$ polu w dalszym ciągu realizowane jest zatłaczanie WAG- $\mathrm{CO}_{2}$. Ponad 30 lat eksploatacji z wykorzystaniem $\mathrm{CO}_{2}$-EOR umożliwiło uzyskanie wysokiego stopnia sczerpania - obecnie około $60 \%$.

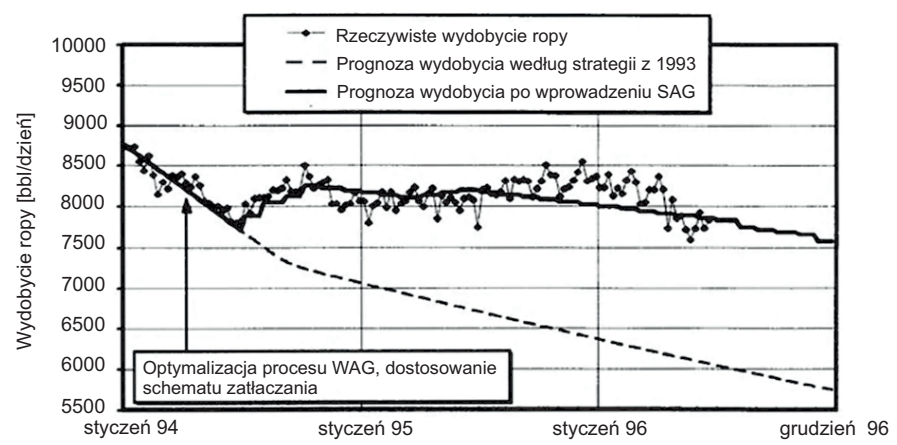

Rys. 12. Porównanie krzywych wydobycia dla $\mathrm{CO}_{2}-\mathrm{WAG}$ i $\mathrm{CO}_{2}$-FAWAG dla EVGSAU (Harpole i Hallenbeck, 1996)

Fig. 12. Comparison of production curves for $\mathrm{CO}_{2}-\mathrm{WAG}$ and $\mathrm{CO}_{2}$-FAWAG in EVGSAU (Harpole i Hallenbeck, 1996)

\section{Podsumowanie}

W niektórych przypadkach złożowych silna heterogeniczność i szczelinowatość formacji złożowych może sprawiać, że proces WAG nie ograniczy wystarczająco mobilności zatłaczanego do złoża gazu. By lepiej przeciwdziałać powstawaniu języków gazowych i przedwczesnemu przebijaniu się zatłaczanego gazu do odwiertów wydobywczych, stosowany jest proces naprzemiennego zatłaczania wody z dodatkiem środka powierzchniowo czynnego (pianotwórczego) i gazu, czyli proces WAG wspomagany pianą (FAWAG). W porównaniu do konwencjonalnego procesu WAG - FAWAG pozwala na dodatkową stabilizację frontu wypierania poprzez zwiększenie lepkości płynu wypierającego oraz blokowanie stref o wysokiej przepuszczalności i skierowanie zatłaczanych płynów do stref nieobjętych wypieraniem. Obecność środków powierzchniowo czynnych pozwala dodatkowo na obniżenie napięcia powierzchniowego, a tym samym na obniżenie sił kapilarnych. Wiele z dotychczas przeprowadzonych implementacji złożowych wykazało, że wykorzystanie metody FAWAG w skałach węglanowych skutecznie opóźnia przebicie zatłaczanych płynów do odwiertów wydobywczych, tym samym powodując znaczny wzrost wydobycia ropy. W tym przypadku zwiększone wydobycie jest zapewnione przez zmniejszenie mobilności gazu, polegające na rozproszeniu fazy gazowej w fazie ciekłej zawierającej środek powierzchniowo czynny. Wartością dodaną stosowania metody WAG lub FAWAG jest możliwość wykorzystania w procesie ditlenku węgla lub niepotrzebnych gazów zasiarczonych lub poprocesowych, co ma pozytywny wydźwięk środowiskowy i może zmniejszyć ślad węglowy wydobywanej ropy (Lubaś et al., 2019).

Artykuł powstał na podstawie pracy statutowej pt.: Laboratoryjne badania efektywności metody WAG (EOR) wspieranej chemicznie $w$ węglanowych skałach zbiornikowych - praca INiG - PIB na zlecenie MNiSW; nr zlecenia: 33/KB/2019, nr archiwalny: KB-4101-33/2019.

\section{Literatura}

Afzali S., Rezaei N., Zendehboudi S., 2018. A comprehensive review on Enhanced Oil Recovery by Water Alternating Gas (WAG) injection. Fuel, 227: 218-246. DOI: 10.1016/J.FUEL.2018.04.015.

Ahmed S., Elraies K.A., Tan I.M., Mumtaz M., 2017. A Review on $\mathrm{CO}_{2}$ Foam for Mobility Control: Enhanced Oil Recovery. ICIPEG 2016. Springer Singapore: 205-215. DOI: 10.1007/978-981-10-3650-7 17.

Almajid M.M., Kovscek A.R., 2016. Pore-level mechanics of foam generation and coalescence in the presence of oil. Advances in Colloid and Interface Science, 233: 65-82. DOI: 10.1016/j. cis.2015.10.008.

Anwar R.A., Teigland R., Kleppe J., 2006. EOR Survey in the North Sea. Society of Petroleum Engineers. DOI: 10.2118/99546-PA.

Bertin H.J., Apaydin O.G., Castanier L.M., Kovscek A.R., 1999. Foam Flow in Heterogeneous Porous Media: Effect of Cross Flow. Society of Petroleum Engineers. DOI: 10.2118/56009-PA.

Blaker T., Aarra M.G., Skauge A., Rasmussen L., Celius H.K., Martinsen H.A., Vassenden F., 2002. Foam for Gas Mobility Control in the Snorre Field: The FAWAG Project. Society of Petroleum Engineers. DOI: 10.2118/78824-PA.

Christensen J.R., Stenby E.H., Skauge A., 1998. Review of WAG Field Experience. Society of Petroleum Engineers. DOI: 10.2118/39883-MS.

Christensen J.R., Stenby E.H., Skauge A., 2001. Review of WAG Field Experience. Society of Petroleum Engineers. DOI: 10.2118/71203-PA.

Farajzadeh R., Andrianov A., Krastev R., Hirasaki G.J., Rossen W.R., 2012. Foam-oil interaction in porous media: Implications for foam assisted enhanced oil recovery. Advances in Colloid and Interface Science, 183-184: 1-13. DOI: 10.1016/J.CIS.2012.07.002.

Farajzadeh R., Andrianov A., Zitha P.L.J., 2009. Foam assisted oil recovery at miscible and immiscible conditions. Society of Petroleum Engineers. DOI: 10.2118/126410-MS. 
Gauteplass J., Chaudhary K., Kovscek A.R., Fernø M.A., 2015. Pore-level foam generation and flow for mobility control in fractured systems. Colloids and Surfaces A: Physicochemical and Engineering Aspects, 468: 184-192. DOI: 10.1016/J. COLSURFA.2014.12.043.

Harpole K.J., Hallenbeck L.D., 1996. East Vacuum Grayburg San Andres Unit $\mathrm{CO}_{2}$ Flood Ten Year Performance Review: Evolution of a Reservoir Management Strategy and Results of WAG Optimization. Society of Petroleum Engineers. DOI: 10.2118/36710-MS

Haugen Å., Fernø M.A., Graue A., Bertin H.J., 2012. Experimental Study of Foam Flow in Fractured Oil-Wet Limestone for Enhanced Oil Recovery. Society of Petroleum Engineers. DOI: 10.2118/129763-PA.

Haugen Å., Mani N., Svenningsen S., Brattekås B., Graue A., Ersland G., Fernø M.A., 2014. Miscible and Immiscible Foam Injection for Mobility Control and EOR in Fractured Oil-Wet Carbonate Rocks. Transport in Porous Media, 104: 109-131. DOI: 10.1007/s11242-014-0323-6.

Kulkarni M.M., Rao D.N., 2005. Experimental investigation of miscible and immiscible Water-Alternating-Gas (WAG) process performance. Journal of Petroleum Science and Engineering, 48: 1-20. DOI: 10.1016/j.petrol.2005.05.001.

Lake L.W., Johns R., Rossen B., Pope G., 2014. Fundamentals of Enhanced Oil Recovery. Society of Petroleum Engineers. ISBN: 978-1-61399-328-6.

Lee S., Kam S.I., 2013. Enhanced Oil Recovery by Using $\mathrm{CO}_{2}$ Foams: Fundamentals and Field Applications. Enhanced Oil Recovery Field Case Studies, 23-63. DOI: 10.1016/ B978-0-12-386545-8.00002-6.

Li R.F., Yan W., Liu S., Hirasaki G., Miller C.A., 2010. Foam Mobility Control for Surfactant Enhanced Oil Recovery. Society of Petroleum Engineers. DOI: 10.2118/113910-PA.

Liu H.S., Chen G., Cao R.B., Han P.H., Lv C.S., Guo S.L., Cui C.Y., 2020. Properties of surfactant solution for foam-flooding. Proceedings of the International Field Exploration and Development Conference 2018. IFEDC 2018. Springer Series in Geomechanics and Geoengineering. Springer: 1370-1380. DOI: 10.1007/978-981-13-7127-1_128.

Lubaś J., 2006. Analiza efektywności metod eksploatacji węglanowych złóż ropy naftowej z podwójnym systemem porowatości. Nafta-Gaz, 9: 444-452.

Lubaś J., 2013. O potrzebie bardziej dynamicznego wdrażania metod wspomagania wydobycia ropy naftowej z krajowych złóż. Nafta-Gaz, 10: 744-750.

Lubaś J., Stopa J., Warnecki M., Wojnicki M., 2019. Możliwości zastosowania zaawansowanych metod wspomagania wydobycia ropy naftowej ze złóż dojrzałych. Nafta-Gaz, 1: 24-28. DOI: 10.18668/NG.2019.01.04.

Manlowe D.J., Radke C.J., 1990. A Pore-Level Investigation of Foam/ Oil Interactions in Porous Media. Society fo Petroleum Engineers. DOI: 10.2118/18069-PA.

Masalmeh S.K., Wei L., Blom C., Jing X., 2014. EOR Options for Heterogeneous Carbonate Reservoirs Currently Under Waterflooding. Society of Petroleum Engineers. DOI: 10.2118/171900-MS.

Pariani G.J., McColloch K.A., Warden S.L., Edens D.R., 1992. An Approach To Optimize Economics in a West Texas $\mathrm{CO}_{2}$ Flood. Journal of Petroleum Technology, 44: 984-1025. DOI: 10.2118/22022-PA.

Prud'homme R.K., Khan S.A., 1996. Foams: theory, measurements, and applications. Marcel Dekker, Inc.
Sanchez N.L., 1999. Management of Water Alternating Gas (WAG) Injection Projects. Society of Petroleum Engineers. DOI: 10.2118/53714-MS.

Schramm L.L. (ed.), 1994. Foams: Fundamentals and Applications in the Petroleum Industry. American Chemical Society. DOI: 10.1021/ba-1994-0242.

Sheng J.J. (ed.), 2013a. Enhanced Oil Recovery Field Case Studies. Elsevier Inc. DOI: 10.1016/C2010-0-67974-0.

Sheng J.J., 2013b. Review of Surfactant Enhanced Oil Recovery in Carbonate Reservoirs. Advances in Petroleum Exploration and Development, 6: 1-10. DOI: 10.3968/j. aped.1925543820130601.1582.

Such J., Szott W., 1997. Symulacyjne badania procesu przemiennego zatłaczania wody i gazu (WAG) stosowanego dla zwiększania efektywności wypierania ropy w złożu. Prace Instytutu Górnictwa Naftowego i Gazownictwa, 89: 21.

Turta A.T., Singhal A.K., 2002. Field Foam Applications in Enhanced Oil Recovery Projects: Screening and Design Aspects. Journal of Canadian Petroleum Technology, 41(10). DOI: 10.2118/02-10-14.

Verma M.K., 2015. Fundamentals of Carbon Dioxide-Enhanced Oil Recovery $\left(\mathrm{CO}_{2}\right.$-EOR $)$ - A Supporting Document of the Assessment Methodology for Hydrocarbon Recovery Using $\mathrm{CO}_{2}$-EOR Associated with Carbon Sequestration. U.S. Geological Survey Open-File Report, 19. DOI: 10.3133/ofr20151071.

Wang J., Han M., Fuseni A.B., Cao D., 2015. Surfactant Adsorption in Surfactant-Polymer Flooding for Carbonate Reservoirs. Society of Petroleum Engineers. DOI: 10.2118/172700-MS.

Weaire D., 2008. The rheology of foam. Current Opinion in Colloid \& Interface Science, 13: 171-176. DOI: 10.1016/J. COCIS.2007.11.004.

Wojnicki M., 2017a. Experimental investigations of oil displacement using the WAG method with carbon dioxide. Nafta-Gaz, 11: 864-870. DOI: 10.18668/NG.2017.11.06.

Wojnicki M., 2017b. Wspomaganie wydobycia ropy metodą naprzemiennego zatłaczania wody i gazu (WAG). Wiadomości Naftowe $i$ Gazownicze, 8: 4-8.

Wojnicki M., Warnecki M., Kuśnierczyk J., Szuflita S., 2017. Ocena skuteczności wypierania ropy metodą WAG z wykorzystaniem gazów kwaśnych. Praca statutowa INiG - PIB, nr zlec. 1887/ KB/2017, Archiwum Instytutu Nafty i Gazu - Państwowego Instytutu Badawczego, Kraków.

Xue Z., Panthi K., Fei Y., Johnston K.P., Mohanty K.K., 2015. $\mathrm{CO}_{2}$ Soluble Ionic Surfactants and $\mathrm{CO}_{2}$ Foams for High-Temperature and High-Salinity Sandstone Reservoirs. Energy and Fuels, 29: 5750-5760. DOI: 10.1021/acs.energyfuels.5b01568.

Yan W., Miller C.A., Hirasaki G.J., 2006. Foam sweep in fractures for enhanced oil recovery. Colloids and Surfaces A: Physicochemical and Engineering Aspects, 282-283: 348-359. DOI: 10.1016/J. COLSURFA.2006.02.067.

Zhang L.-M., Zhu Y.-Y., Zhou L.-F., 2005. State of the art of foaming agents in hightemperature steam foam flooding. Symposium on Tertiary Recovery, 363-367.

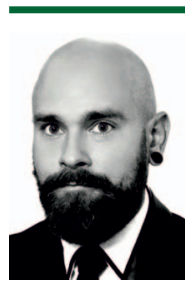

Mgr inż. Mirosław WOJNICKI

Asystent w Zakładzie Badania Złóż Ropy i Gazu

Instytut Nafty i Gazu - Państwowy Instytut Badawczy ul. Lubicz $25 \mathrm{~A}$

31-503 Kraków

E-mail: miroslaw.wojnicki@inig.pl 